\title{
A Dynamic World Insurance Industry Essential to Stable Growth? A Comment from a Practitioner
}

\author{
by John M. Stoker*
}

\section{Introduction}

This is, with apologies, strictly a practitioner's view and indeed that of an ex-practitioner since ten years have elapsed since I finished a 20 year period building and managing insurance broking operations. Nevertheless my subsequent work as a strategic thinker within a major broking group and more recently as a consultant to the insurance industry and its customers has given me ample time to reflect on these prior experiences. I am also not a trained economist, but have always been alert to what a generation of economists and planners were trying to achieve, often under United Nations sponsorship, during the decades which followed the Second World War.

My working career led me to experience simultaneously daily business life in the developing economies and in that most stimulating of markets, the USA, during the 1960's and the 1970's. The reason for this lays, of course, in the historical coincidence of working during the heyday of the entrepreneurial intermediary, when the world had been shrunk in size by the jet plane but had not yet undergone the revolution in communications. Many also forget that the USA had only just emerged from the post-depression era of trade barriers and excessively detailed regulation - prolonged in regulatory terms by the World War - and was itself but recently maturing into a relatively open and competitive market place, largely as a direct result of this intermediary stimulus.

The US, with customary efficiency, adopted the resultant ideas, improved upon them, and now exports knowhow, but at this overlap period this had yet to happen. It is also interesting to note that the US had just completed two decades of exceptional growth in Life Insurance; subsequently this growth moderated and activity switched to the Non-Life sector. I will comment further on this phenomenon later.

In the early '70's, therefore, extreme contrasts were daily evident to this practitioner, and one felt frustration at being actively prevented from doing a professional job for new clients in the Third World during an apparent boom-time because of protectionist practices.

* TILLINGHAST, London. Paper presented at the second ASEC (Applied Service Economics Centre) meeting in Geneva (May, 1991). 
It felt obvious to experienced intermediaries that the model promoted by UNCTAD and other well-meaning bodics was depriving those markets of that most precious commodity, technology transfer, and that protectionism, promoted by a species of neutral paternalism. was actually increasing the outflow of funds from the subject economies. Vigorous arguments were frequent, but to no avail. In any event these adverse effects of textbook rules were masked by the investment boom which followed the first great oil price rises. Third World insurers maintained their privileged domestic existences, and inefficiencies, yet rushed to participate in the harsh world of commercial risk and reinsurance underwriting in major centres. Dreams of healthy reciprocal trading were subsequently shattered and many incurred substantial debts, many of which remain unsatisficd today alongside the loan defaults.

The real and final enemy was of course the vicious inflation which followed the vast inflow of capital. Tentative efforts were made to encourage savings through models well tried in the developed world, via Life insurance products, mortgage products offered by new savings banks and so forth, but behind a wall of exchange controls. The thirst for knowledge was great, but actual investment by experienced outsiders was scldom permitted. In any event, as is now apparent, huge inflationary forces overwhelmed and virtually destroyed most of these efforts, and even the experiments in indexation such as those in Brazil failed to compensate fully for the cffects.

This is, then the introduction to what, it may be felt, is a polemic rather than a measured dissertation, but at least I feel there are now grounds for some optimism. If the achievements of post-war economists, planners and legislators were the precise opposite of what was intended, for the best of motives, then the results were so manifestly bad that a different climate must emerge. Indeed current practitioners tell me that the insurance industry in some third world countries is in such a shambles that, de facto, the change to an open buying environment has already occurred. Peru was quoted as an example. This is not a desirable consequence, for it prevents this part of the financial services industry from performing its basic function: spreading risk in a stable, fair, fashion in a manner which leads to the accumulation of funds for long-term investment within an economy. But, if you will, the slate is wiped clean.

All that has been described above is likewise now demonstrable in the collapse of the Centrally Planned Economies, after in many cases even longer periods of experimentation. It is thus doubly important that a sensible balance between domestic needs and opportunitics for cross-border investment and trade is seen to emerge, and soon.

To summarise the contemporary scene, exclusive of extreme examples such as that just cited, the insurance industries of many developing countries present a somewhat sorry picture, often a century and more after their foundation by companies with global ambitions. Growth has been uneven : public confidence is frequently at a low ebb. The industry is frequently viewed as a necessary evil, rather than as a dynamic force which can aid essential infrastructural growth. Countries starved of development capital, groaning beneath the leaden weight of debt service, still turn instinctively to foreign banks for fresh injections of funds. Insurance, the "step-child of finance and the economy" in the words of the Secretary Gencral of the African Reinsurance Corporation, scldom features in plans for coonomic advancement.

Loan capital represents the "quick fix": the build up of surplus from insurance operations takes too much time, secmingly, and "free" reserves present a tempting target to 
Governments in straitened times. And yet, in developed countries, insurance companies represent the very rock upon which institutional investment capabilities are founded. In addition, when natural catastrophes occur, financial resources arc needed to repair the infrastructure, housing, and key industries. Sufficient funds are frequently not available from domestic reserves, even in the fully developed cconomics, hence the need for sophisticated reinsurance. Short of the catastrophic event the Industry should generate excellent essentially "conservative" long-term capital for use in infrastructural development. In most third world countries the influence is negligible.

\section{The classic post-war model}

Why this huge gulf? The answer can only lie in half a century's expcrimentation with control based upon wcll-meaning but flawed notions of controlling an outflow of funds, perceived as necessary to several gencrations of academic economists. Most of those same economists, if pressed, accepted the principle of a fair rate of return on money invested for industrial development, but for a like expansion in the financial services sector, domestically in a range of personal products and in Life Assurance, and espccially on the intcrnational scale through the medium of reinsurance, apparently not. The reasons for this cntrenched attitude may lie partly in notions which all parts of the world share, for in few countries is the image of the industry one of wclcome - witness the popular wave which gave risc to Proposition 103 in California. Flawed prudential controls, past "imperial" behaviour, and the vulncrability of the industry in times of economic stress undoubtedly also contributed to this prejudice. The Depression years of the 1930's gave rise to rigorous controls in many countries, including the US, and at that time the regulations which established the IRB in Brazil, the INdeR in Argentina, Banco de Seguros in Uruguay must have seemed quite enlightencd.

These experiments must have appeared very logical: products could be copied, "manufactured" locally using local resources; foreign intervention was unnecessary and such help as was required could be processed via the monopoly reinsurer. Thus, with national variations, there followed outright nationalisations, crceping nationalisations in the form of remittance controls, bans on ncw foreign investment. Stultifying "tariffication" provided some underpinning to solvency but stifled competition. Large, but in reality unearned, intermediary commissions raised expense ratios. The resultant inefficiencies further eroded public confidence. The products "manufactured" remained frozen, for the most part, in the pre-Volkswagen age. Industries and the insurance profession which could serve them, and the populacc, suffercd from the same malaise; but insurance is not especially capital intensive, so the tragedy of missed development opportunity became the more stark.

Reinsurance, however, has always been a necessity, to protect large accumulations of value in industrial developments, and cumulative exposures through Personal Lines to natural catastrophe. In support of the currency-drain theory, a monopolistic approach to contracting with the devcloped world was adopted. Local pooling prior to cession abroad emerged to become the norm: admirably logical, yet reinsurers or retrocessionaires external to the economy participated with the dice loaded against them, fighting attempts to impose premium and loss reserve retentions with artificially low interest rate earnings on even facultative cessions. Reinsurance should be a two-way bet but became onc-way; on the occurrence of natural catastrophes the demand for funds is enormous ("Cash on the nail, 
please, and overlook late payment of the remaining premium balance for past years") but reinsurers were not to be allowed to accumulate reserves in a free investment climate, which this global industry needs to fund major losses even in highly developed economies. To illustrate the importance of this sector of the industry, a recent study has calculated that a repeat of the 1923 Tokyo earthquake would exhaust the domestic and global reinsurance industries' combined committed funds and cause Japanese growth in GNP to be negative.

Reinsurers thus were forced to compete for minute shares of Fire Treaties at absurd ceding commissions (padded by ridiculously high brokerage to local brokers) which represented very poor value for money to the front end consumers, combined with the maximum offer of catastrophe peril cover, carrying with it exposure to the inevitable cash loss demand for catastrophe. Liability business, a useful engine for compensating the unfortunate in society, was held in check by nervous insurers. A rigid investment environment, ill developed laws, and distortions caused by inflation in any event rendered product pricing hazardous. The result: only token offers of front-end cover offered by local direct insurers.

Worse still, the monopolies often insisted on an absurd fragmentation of their business portfolios which afforded slim chance of profit to those external reinsurers, little continuity of relationship and negligible incentive for technology transfer. This occurred only in cases of near monopoly for some of the major professional reinsurers, but at a high cost; in these instances pricing was seldom keen and the feared drain of resources often became a reality, until curtailed in panic. The academic economists' fears of currency drain seemed justified. The attitude adopted by commercial reinsurers was equally justifiable. To me, as a layman, the overkill was astonishing. Reinsurance volume normally should approximate to $15 \%$ of direct non-life volume, which in a reasonably developed market at that time might represent $2 \%$ of GDP. The annual balance, as stated above, was always fine, and frequently in favour of the host country.

In any event, there were exceptions, especially in the case of the major state-sponsored infrastructural developments of the oil boom years. I had personal experience of some of these. Venezuela permitted some carefully constructed reinsurance programmes for such developments to be implemented, severely controlling local commissions to the indigenous insurers and utilising a free market approach to world markets. The result was finely-priced and very broad coverage, smooth and prompt payments, to and from those markets. Saudi Arabia, through the quirks of Islamic Law rendering the infant industry initially unregulated, became an open market. Financial executives utilised best international practice in securing well-planned insurance protections as keenly judged for quality as the materials and workmanship in the new road system, simply because restrictions did not, at least initially, exist.

These were, however, rare exceptions and required months of painstaking negotiation. As a result, most developing countries exposure to material catastrophe was left only partially covered. The Central American earthquakes of the '70s' and, more recently, Hurricane Hugo in the Caribbean, demonstrated this, as have many tragic natural events. Tragically, even these partial benefits of insurance seldom reach far towards the populace at large, only certain key industrial installations. Economic recovery is retarded for years.

\section{Insurance in the developing world today}

Thus, in most undeveloped countries the industry is totally lopsided. Reinsurance, providing a conduit, albeit an imperfect one, for the import of new practices, functions to 
ensure partial protection against major hazard-losses incurred in the commercial and industrial sector. Prescribed methods of operation render it only partly efficient and State Treasurers watch over it closely to contain the perceived currency drain. Reinsurers, for their part, bemoan the unbalanced nature of their book of business and impose ceilings on exposure to aggregating losses through catastrophic perils. The original concept of reciprocal trading between major reinsurers seems a distant dream.

Meantime, the domestic services afforded within the host economies are for the most part inefficient by the standards of developed countries, bound by tariffs and perceived as affording poor value for money by the public. Only where coverage is compulsory, as in Motor insurance, does sufficient volume of business develop to promote a semblance of competition, and the volume of premium produce markets whose performance can usefully be compared with those of developed countries.

Life insurance, an important indicator of public confidence, is threatened by inflationary forces in many undeveloped markets; thus growth remains illusory. This in turn deprives insurers of long-term funds to manage for the benefit of the economy. Their need to concentrate on short-term coverages completes the vicious circle; the potential for investment of fiduciary funds presents limited choice with an over concentration in real estate and state-sponsored bonds; this in turn provides a disincentive to extend property insurance into the catastrophe peril area, increasing dependence on reinsurance. Foreign insurers still operating under the "grandfather" principle, often now in minority shareholding positions, in these restricted markets are similarly constrained and must act like the local peer group. There is little incentive for further investment.

The result is therefore that insurance is prevented from assuming its full potential, as a promoter of open and liquid investments and as a repository for savings of individuals. The economy also might suffer loss of momentum at a delicate stage of its growth.

This is a gloomy picture, but I make no apologies for this, since the statistics speak for themselves and illustrate graphically the failures of attempts to manage and control this important financial function. The Swiss Re has tracked the growth and composition of most national insurance markets for many years in their admirable "Sigma" publications. In 1988 $91 \%$ of world premium income came from OECD countries, and of this $90 \%$ from the major seven group of nations. Life insurance volume exceeded Non-Life in 19 countries, somewhat distorted by active promotion through favourable taxation treatment in Japan and other Far Eastern markets and by the unnatural position of Life insurance in the USSR and Eastern Europe where the potential for Non-Life coverages has been severely distorted by political dogmatism, and the absence of a concept of Property value. In a truly free market the two parts of the sector should probably be in balance.

More graphic is the position in undeveloped market economies or those which are inflation-prone. Thus, in Africa excluding South Africa and Zimbabwe, Life Insurance represents only $11.7 \%$ of total premium income. In Argentina the proportion is a meagre $8 \%$; in Brazil $12 \%$. In Yugoslavia the figure is $2.3 \%$. In many cases the proportion has dropped over the last decade and inflation is, of course, the primary cause, sometimes exacerbated by political uncertainties.

\section{The wider view}

Per capita expenditures on insurance range from approximately US $\$ 2,300$ in Switzerland and Japan down to just $\$ 2.40$ in Nigeria. In Japan the aggregate turnover of 
the industry now represents $9.78 \%$ of GDP, and has been and still is a major motor-force in the growth of the economy. In Nigeria that figure is $1 \%$ and heavily loaded towards the commercial sector.

There are some bright spots. In Chile, where major efforts have been made to open up the economy and entry barriers to outsiders have been first significantly lowered then virtually abolished, there has been explosive growth in Life insurance which now represents half of that market's income. Modern approaches to Non-Life insurance have also been welcomed, allied to risk management principles, for example in the important forestry industry. All forms of savings are encouraged; a stock market again operates.

Far Eastern markets are also instructive. Here, as mentioned, a sympathetic tax regime has promoted growth in Life insurance as an additional savings medium and engine for investment, draining away some funds from the personal sector which would otherwise have fuelled personal consumption. Growth in Accident insurance, perhaps as a part surrogate for social security, is now piggy-backing on this expansion. The figures are very large indeed for the Life Sector in some of those markets: over $5 \%$ of GDP in Japan and South Korea. Life premiums thus represent more than all forms of private saving in the USA, and they are nicely locked in for use in long-term investment.

The common factor is, of course, persuading the public to part with funds in the belief that a real return will result, and that risks inherent in daily of business life will be equitably spread, for a modest fee. These examples present a strong argument for use of this sector to promote growth in the economy without over reliance on outside assistance. The resultant expansion in stock market activity then creates a more favourable environment for the development of non-life products for the personal sector and corporate customers alike.

\section{What should now happen?}

The Pacific Basin option may, however, be hard to follow in many economies since there are strong, and differing, cultural influences at work. For a start, though, most national non-life markets should be opened up to competitive forces free of controls other than those designed to ensure the solvency of domestically-supervised insurers. "Privatisation" is the buzz-word, but what does it mean? Distributing the meagre capital of state-owned enterprises in $\$ 50$ parcels, per se, achieves nothing. Sale to outsiders in monolithic form may import the prejudices of the buyer. Entrenched management practices will alter slowly. Competition will be needed to increase efficiency and the rapid transfer of new technologies and know-how. That process can be observed today in some European Community markets; as already mentioned 30 years ago it took place in the US, so successfully that that country now exports know-how in techniques of risk management and many forms of innovative insurance product. Yet in my working lifetime it is possible to recall an impossible bureaucracy functioning in each of 50 states mandating rates, policy forms, the minutiae of investment of funds by insurers and layer upon layer of licence requirements before competition was possible. Large direct insurers relied on reinsurance to an extent impossible to envisage today. In the EC very recently there has been explosive growth of the Insurance Industry in Spain since that country joined the Community. The industry in Ireland, out of understandably chauvinistic attitudes set in the ' 30 's, has fallen into majority foreign ownership but in such a competitive atmosphere that the result is a de facto inflow of funds, to the benefit of the economy and its consumers. Ireland now appears not to wish to avail itself of the derogation period afforded under the second Non-Life Directive. 
Achieving liquidity in insurers ' assets should also receive priority, if products which are responsive to policyholders' demand are to be produced on a cost-efficient basis, and localisation of those assets should follow as fast as possible but only to the extent that a reasonable range of investment media are developed. Competitive forces should meantime ensure that operating profits are minimised so that new entrants to previously restricted markets de facto receive only a fair return on capital employed. This is amply demonstrated by actual experience in really open markets where insurers, domestic and foreign, have a struggle to prosper. In those markets, sages talk about distortions in the insurance cycle: a couple of "good" years followed by eight "bad" ones. All this illustrates is the very rapid response mechanism of the industry due to the potential large return on capital employed if product pricing coincides with a favourable investment climate. Capital floods in, and the resultant competition is bloody and long until the excess is squeezed out. Meantime the consumer benefits.

Nor, I would suggest, does nationality of company really matter, any more than it does in motor manufacture. Financial Services has a great deal to learn from the sophisticated consumer goods sector. Branding of products on a global basis is blurring these distinctions in the eyes of the public, if not to Treasury economists; yet even they must, in truth, be hard put to track the real flow of parts round the world and constantly changing transfer pricing mechanisms. I, as a consumer, no longer know, or care, whether my Sanyo, my Ford, my Olivetti, is made across the world from parts produced next door to me, or vice versa. I only care that fair value for money and a good reliable product, backed by after sales service, arrives at my house.

\section{The role of reinsurance}

Earlier in this paper $I$ have made mention of the problems which the important Global Reinsurance industry has been forced to confront. It is noteworthy that in free, or nearfree, markets the reinsurance mechanism can not only facilitate change but positively accelerate the process. For this reason it is significant that the European Community recognised the importance of the function in its first significant insurance-related Directive, a full ten years before any counterpart move concerning direct insurance.

Trading between the US and the rest of the World is also instructive. I have made mention of the important role of liability insurance as a follow-on to Life Insurance development in countries where there is a sophisticated investment climate. Freedom to reinsurance on a global basis adds exponentially to this process. Many reinsurers in London and European markets perhaps regret the consequences of this freedom, since in the US they found themselves to be almost unwitting participants in evolving social policies: Courts have interpreted liability insurances retrospectively so that they have become an instrument in the socio-political struggle between the Welfare State ideal and those of seeking solutions to emerging problems through the free markets via the adversarial legal system. The common theme is that an individual member of Society seen to have been "harmed" by others through no fault of his/her own should be compensated.

Reinsurers may regret the results of this process but it was, in the truest sense of the term, "efficient". The free market, perhaps, has gone mad, but is playing a part in a process of rapid change with real political significance. 


\section{A formula for the future}

Let us now select a few relevant points for consideration of how future effort should be directed. The first is the influence of Life Insurance in economic development, provided that inflationary forces are under reasonable control (experience in Chile would seem to indicate that rates deemed undesirablc but not threatening of hyper inflation will be tolerated). Provided that the insurance industry is perceived by the public as "safe" and that taxation treatment is favourable, this captures funds for infrastructural development purposes on a more secure long-term basis than most other forms of investment offered to the personal sector. Its use is thus easy to encourage. Reconstruction may be the motive, as was presumably the casc in the post-Dcpression cra in the US; morc aggressive utilisation may be adopted as has been the case in Japan.

Second, insurance cannot function effectively as a savings medium as opposed to a risk protection without a well developed capital market which offers liquidity. Third, the existence of such a market will influence the rate at which Non-Life insurance which carries connotations of long-tail liability will develop. Fourth, the same factor will determine the Non-Life insurers ability to afford cover for the risks of natural catastrophe where the shortterm demand for cash is self-evident, through accumulation of individual losses. This will directly affect the extent to which the important reinsurance sector's support is required. Fifth, that sector will only afford substantial support if it can approach a market on a long term basis, fulfilling its classic role of smoothing out the financial consequences of a catastrophic event over time, apparently "profiting" short-term.

Sixth is the import of modern practice, applied sector by sector. Compulsory Motor Liability insurance is now universally perceived as socially desirable. Less often perceived are the merits of risk management techniques, which can be actively promoted, either by regulation or by recommended practice. These span a wide gamut of activities, assessing risks so as to direct risk control efforts, and introducing mandated insurance coverage for, as examples, physical damage to major construction projects and protection of future revenues, and liability risks for environmental impairment. At the microlevel of infrastructural development crop insurance and equipment insurance can promote good husbandry in agriculture and encourage prudent use of financial resources. Compulsory insurance, often allied to strict liability as in many European countries is a powerful driver of good behaviour. Collective risk financing schemes often arise even in the absence of conventional cover.

Finally, competitive forces will ensure that an industry which is frequently somewhat over-capitalised fights fiercely for market-share in all newly opened markets and frequently makes minimal profits in the process. This is the major difference between the electronic ' 90 's and the age of world travel by steamships.

My conclusions are these. It is sad that discussions aimed at liberalisation of trade in this part of the financial services sector have been perceived as tied to negotiations regarding trade in commodities and physical goods. Every effort should be made to decouple since insurance related services are unlikely in the future to drain the resources of developing countries. On the contrary the import of best practice, through investment or by crossborder trade is of vital importance.

Above all, planners should take the time to study the use of insurance products sector by sector and determine the appropriate mix for the relevant economy. Fiscal and regulatory 
measures should be adopted which then actively encourage those which contribute the most, with imported knowhow. In short, a broad added-value test. Otherwise their main priority should be to ensure, as far as possible, that their home industry is prudently run, adequately capitalised, and enter into frequent communication with regulators in other countries. It is to be hoped that the insurance industry will follow the example of the Basle agreement in the banking sector in order to simplify this task.

The title of this brief paper uses the word "dynamic", and by this I wished to imply that a value-added approach was required, applicable sector by sector across the spectrum of insurance products, not on sum-total basis. It is my sincere belief that this is the best way for the forces of the free markets to be brought to bear on the important task of promoting good infrastructural development and good standards of personal and corporate behaviour in society. I have seen the process at work, slowly and with undue delays, in past days under extremely restrictive conditions. Such energies unleashed and carefully channelled can achieve much and take considerable burdens away from other hard-pressed government agencies.

A sound insurance industry is a vital component in a country's transition from undeveloped to developed. At its best, it can be the engine of such transition.

Protectionism has failed to help developing countries. Corporations in developed countries are willing to make investments, under the right conditions. There is a need to change the conditions, but I am dismayed by the tortuous process of the GATT negotiations. As a consequence my belief is that some form of separate initiative is required, led by the principal developed countries, promoting the concept of a "level playing field" and freemarket competition.

Regulators, and national negotiators in all international discussion forums should, in my view, concentrate solely on home country solvency issues, nothing else. In this respect, and as a practitioner in the "stepchild" context of financial services, one must reluctantly concede that the Banks are ahead. But, I would argue, the Insurance and Reinsurance industry is, at the end of the day, more user friendly. 